Division of Geological \& Geophysical Surveys

RAW-DATA FILE 2013-6

\title{
MERCURY INJECTION CAPILLARY PRESSURE (MICP) RESULTS FROM OUTCROP SAMPLES IN THE NAKNEK FORMATION, INISKIN PENINSULA, ALASKA
}

by

Andrea M. Loveland and PetroTech Associates

$\$ 2.00$

September 2013

THIS REPORT HAS NOT BEEN REVIEWED FOR

TECHNICAL CONTENT OR FOR CONFORMITY TO THE

EDITORIAL STANDARDS OF DGGS

Released by

STATE OF ALASKA

DEPARTMENT OF NATURAL RESOURCES

Division of Geological \& Geophysical Surveys 3354 College Road

Fairbanks, Alaska 99709-3707 



\title{
MERCURY INJECTION CAPILLARY PRESSURE (MICP) RESULTS FROM OUTCROP SAMPLES IN THE NAKNEK FORMATION, INISKIN PENINSULA, ALASKA
}

\author{
by
}

\author{
Andrea M. Loveland ${ }^{1}$ and PetroTech Associates ${ }^{2}$
}

\begin{abstract}
${ }^{1}$ Division of Geological \& Geophysical Surveys, 3354 College Road, Fairbanks, Alaska 99709-3707; andrea.loveland@alaska.gov
${ }^{2}$ PetroTech Associates, 11767 Katy Freeway, Suite 320, Houston, Texas 77079
\end{abstract}

\section{INTRODUCTION}

This report summarizes mercury injection capillary pressure (MICP) data for nine outcrop samples collected from the Naknek Formation on the Iniskin Peninsula in Cook Inlet. Samples were collected from a measured stratigraphic section, with the exception of samples 12MAW105b, 12MAW114b, 12MAW114e, and 12MAW115b (fig. 1). Measured section sample coordinates represent the location of the bottom of the stratigraphic measured section. All samples were analyzed by PetroTech Associates, Houston, TX.

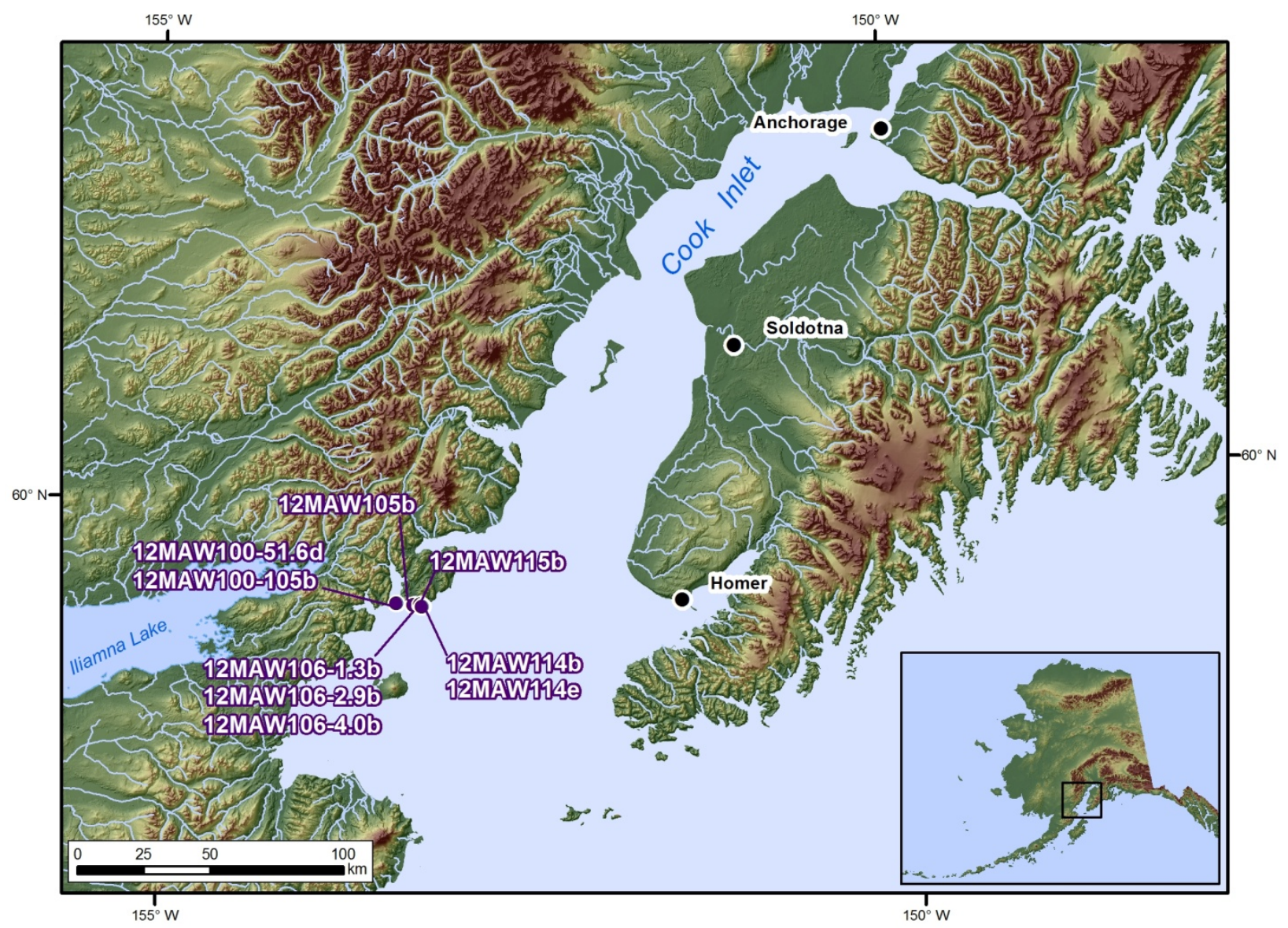


Figure 1. Shaded relief map of the Cook Inlet area, showing the locations from which nine outcrop samples were collected for MICP analysis.

\section{DATA FILES}

The data for this publication are provided in their native spreadsheet format. The citation index page for this publication is http://www.dggs.alaska.gov/pubs/id/25494. The digital dataset includes:

- Sample names, coordinates, and the formation from which samples were collected.

- $\quad$ Per-sample pore volume and aperture size distribution plots and data.

- Composite plots of pore volume.

- Composite plots of pore aperture size distribution.

A detailed description of the digital data files can be found in the associated metadata file.

The following pages include correspondence from PetroTech Associates describing the methods used in MICP analyses of the samples in this report, a brief summary of the data, and references cited. 


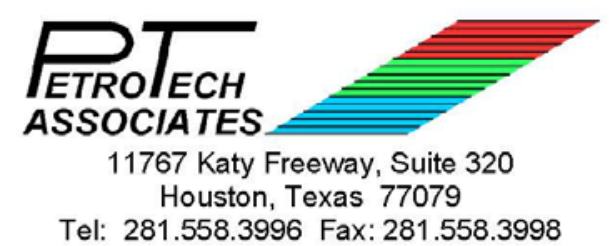

February 25, 2013

Ms. Andrea Loveland

Alaska Division of Geological \& Geophysical Surveys

3354 College Road

Fairbanks, AK 99709

Dear Andrea,

PetroTech has completed high-pressure mercury injection capillary pressure analysis of nine (9) outcrop samples from the Lower Cook Inlet, Alaska. The sample designations are listed in Table 1.

Following receipt of the samples, a representative portion of each was trimmed to fit the sample holders and examined under reflected light microscopy to note any irregularities that might affect the data quality. The rock surfaces were cleaned of any mud or dust and the samples then dried to a constant weight in a low temperature oven before being analyzed.

During capillary pressure testing, the volume of mercury injected was measured at 118 pressure points from 1.64 to 59,500 psia. These data were then corrected for closure. The "closure" volume is the amount of mercury intrusion that occurs as the mercury conforms to the sample surface, filling any irregularities, prior to entering the pore system. A table of the data and separate plots of cumulative bulk volume and wetting phase saturation versus capillary pressure, as well as the incremental pore aperture size distribution, are included for each sample. Composite plots of the drainage data (Figure 1) and pore aperture size distributions (Figure 2), as well as a series of "thumbnail" pore aperture size distribution plots (Figure 3 ) are provided, as an aid when comparing samples.

Table 1 contains the porosity and permeability values derived from the capillary pressure testing. The porosity is based on an Archimedes bulk volume and the closure corrected volume of mercury injected during testing (pore volume). The permeability is calculated using the Swanson equation (SPE, 1981) and the cumulative bulk volume and capillary pressure at maximum intrusion. The values are summarized below:

\begin{tabular}{|c|c|c|c|}
\hline \multicolumn{2}{|c|}{ Porosity } & \multicolumn{2}{c|}{ Permeability (air) } \\
\hline Average & Range & Geomean & Range \\
\hline $3.01 \%$ & $1.93-5.41 \%$ & $0.00029 \mathrm{md}$ & $0.00011-0.0018 \mathrm{md}$ \\
\hline
\end{tabular}

Figure 3 
The capillary pressure data is displayed in Figures 1 through 3 , and information on the pore system properties is also contained in Table 1. The samples have pore structures that exhibit varying character. A majority of the rocks exhibit some level of bimodality, with the exceptions being samples $105 \mathrm{~b}$ and $106-2.9 \mathrm{~b}$ which have unimodal intrusion profiles. Figure 1 shows that, although there is an overall large range in the air/mercury capillary entry pressures, some similarities exist. The intrusion profiles (Figures 2 and 3) for the five samples with the lowest entry pressures ( 9 psia to $65 \mathrm{psia}$ ) are the broadest, indicating the pore structures are the most heterogeneous. The two samples with the unimodal intrusion profiles have the highest entry pressure (964 psia) and the most homogeneous pore structures.

The portion of the intrusion profiles, corresponding to capillary pressures above 1000 psia, includes what is the dominant peak in most of the samples. Maximum intrusion occurs over a pore aperture size range from 0.031 microns to 0.015 microns. The amount of the pore volume accessed by these peaks averages $74 \%$ of the total, and the range is from $50 \%$ to $100 \%$.

Samples $105 \mathrm{~b}$ and $106-2.9 \mathrm{~b}$, that have the more defined unimodal intrusion profiles and higher entry pressures, have overall capillary properties that would make them moderately good quality Type B seals in the Sneider Classification.

PetroTech has assigned project code PA -1196 to this study. We appreciate the opportunity to provide these services. Please contact us with any comments or questions regarding the data or analytical procedures.

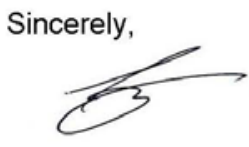

George Bolger

\section{References cited}

Swanson, B.F., 1981, A simple correlation between permeabilities and mercury capillary pressures, Journal of Petroleum Technology, pp 2498-2504.

Sneider, R.M., 1991, Petrophysical properties of seals, in Seals, Traps and the Petroleum System, AAPG Memoir 67; R.C. Surdam (Ed.); American Association of Petroleum Geologists, Tulsa, OK, 317 p. 
TABLE 1

Pore System Properties

Lower Cook Inlet

\begin{tabular}{|c|c|c|c|c|c|c|c|c|}
\hline \multirow[b]{2}{*}{ Sample } & \multicolumn{2}{|c|}{ Mercury Derived } & \multirow[b]{2}{*}{$\begin{array}{c}\text { Median } \\
\text { Aperture } \\
\end{array}$} & \multirow{2}{*}{$\begin{array}{c}\text { Air/Mercury } \\
\text { Capillary Entry } \\
\text { Pressure (psia) } \\
\end{array}$} & \multirow[b]{2}{*}{ Pore Structure } & \multirow{2}{*}{\multicolumn{3}{|c|}{ Aperture Size at Peak Locations }} \\
\hline & $\begin{array}{c}\text { Porosity } \\
\text { (\%) }\end{array}$ & $\begin{array}{l}\text { Kair } \\
\text { (md) }\end{array}$ & & & & & & \\
\hline 12MAW100-51.6d & 2.25 & 0.00012 & 0.1393 & 11.8 & poorly defined bimodal & ? & 0.0149 & \\
\hline 12MAW100-105b & 5.41 & 0.0018 & 0.0849 & 22.2 & moderately bimodal & 2.500 & 0.0307 & \\
\hline 12MAW105b & 2.31 & 0.00012 & 0.0187 & 964 & unimodal & 0.0196 & & \\
\hline 12MAW106-1.3b & 1.93 & 0.00011 & 0.0448 & 59.6 & poorly defined polymodal & ? & 0.265 & 0.0149 \\
\hline 12MAW106-2.9b & 2.38 & 0.00024 & 0.0261 & 964 & unimodal & 0.028 & & \\
\hline 12MAW106-4.0b & 3.03 & 0.00041 & 0.0321 & 229 & slightly bimodal & 0.379 & 0.028 & \\
\hline 12MAW114b & 3.61 & 0.0008 & 0.0643 & 65.2 & moderately bimodal & 0.850 & 0.0307 & \\
\hline 12MAW114e & 1.93 & 0.00011 & 0.0292 & 328 & poorly defined bimodal & 0.290 & 0.0149 & \\
\hline 12MAW115b & 4.21 & 0.00059 & 0.2030 & 9.04 & bimodal & 1.460 & 0.028 & \\
\hline
\end{tabular}

Calculated at peak intrusion

Aperture size in microns

dominant peak 
FIGURE 1

Mercury Injection Capillary Pressure (Pore Volume)

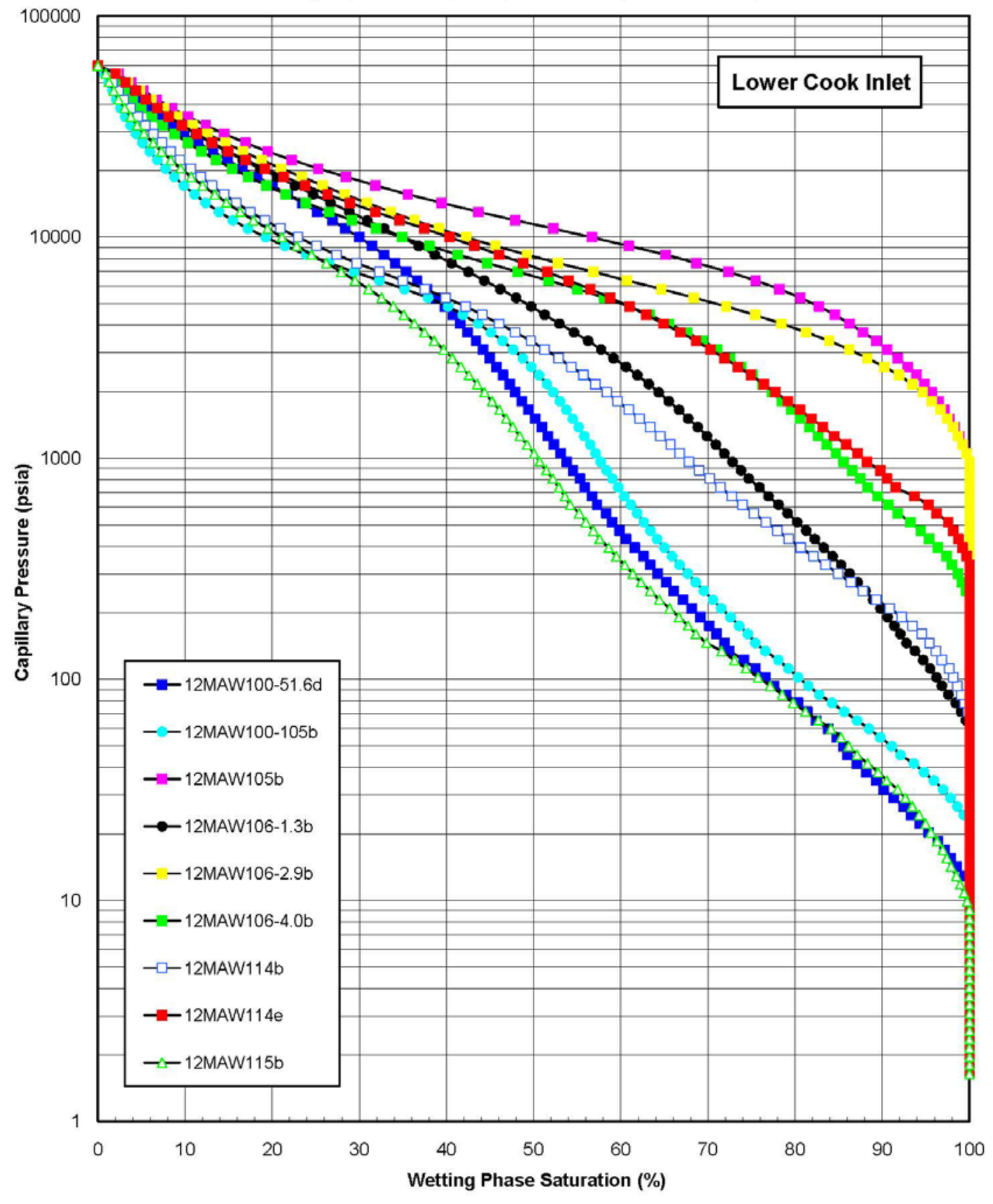




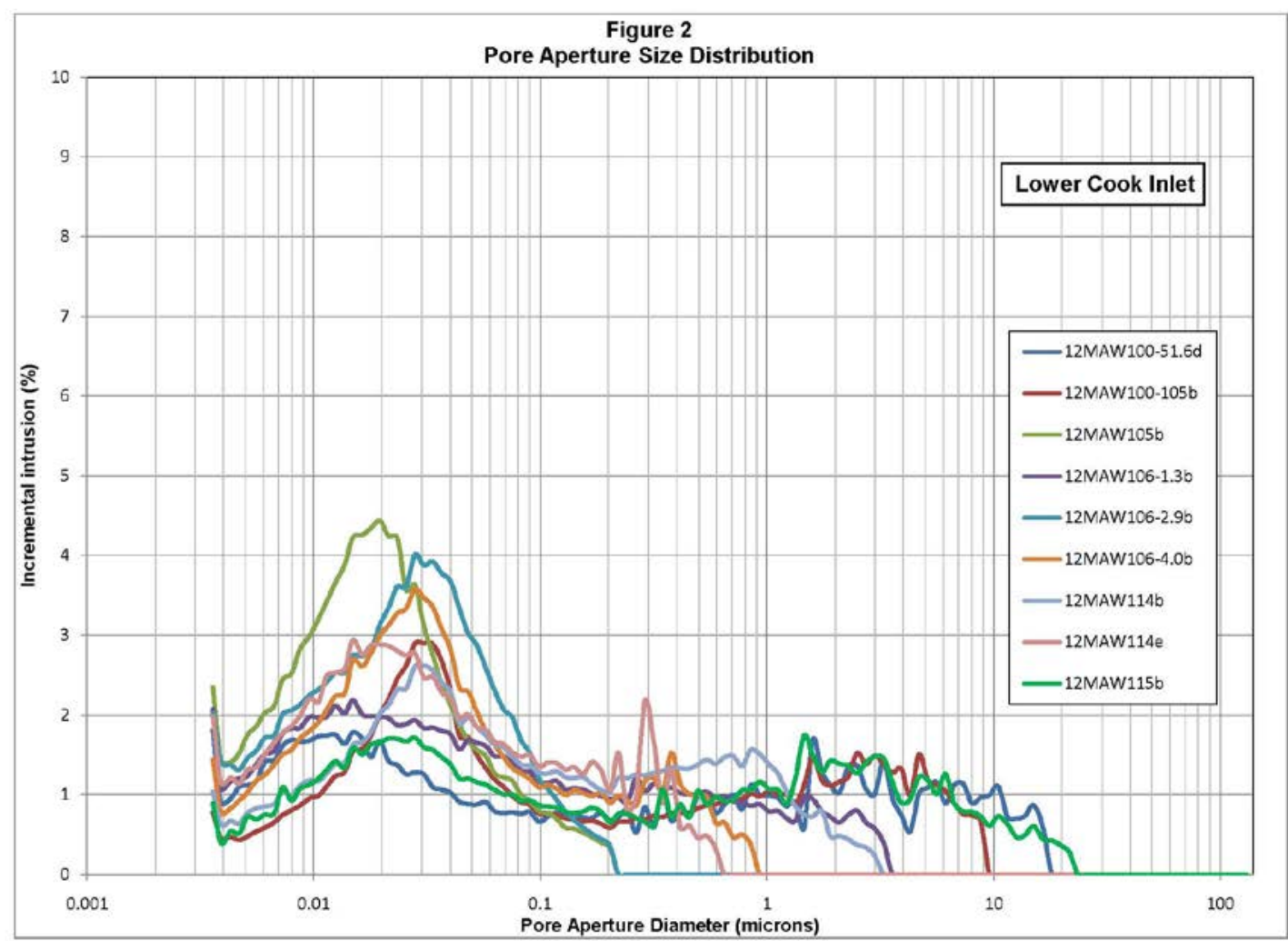


FIGURE 3a

Lower Cook Inlet
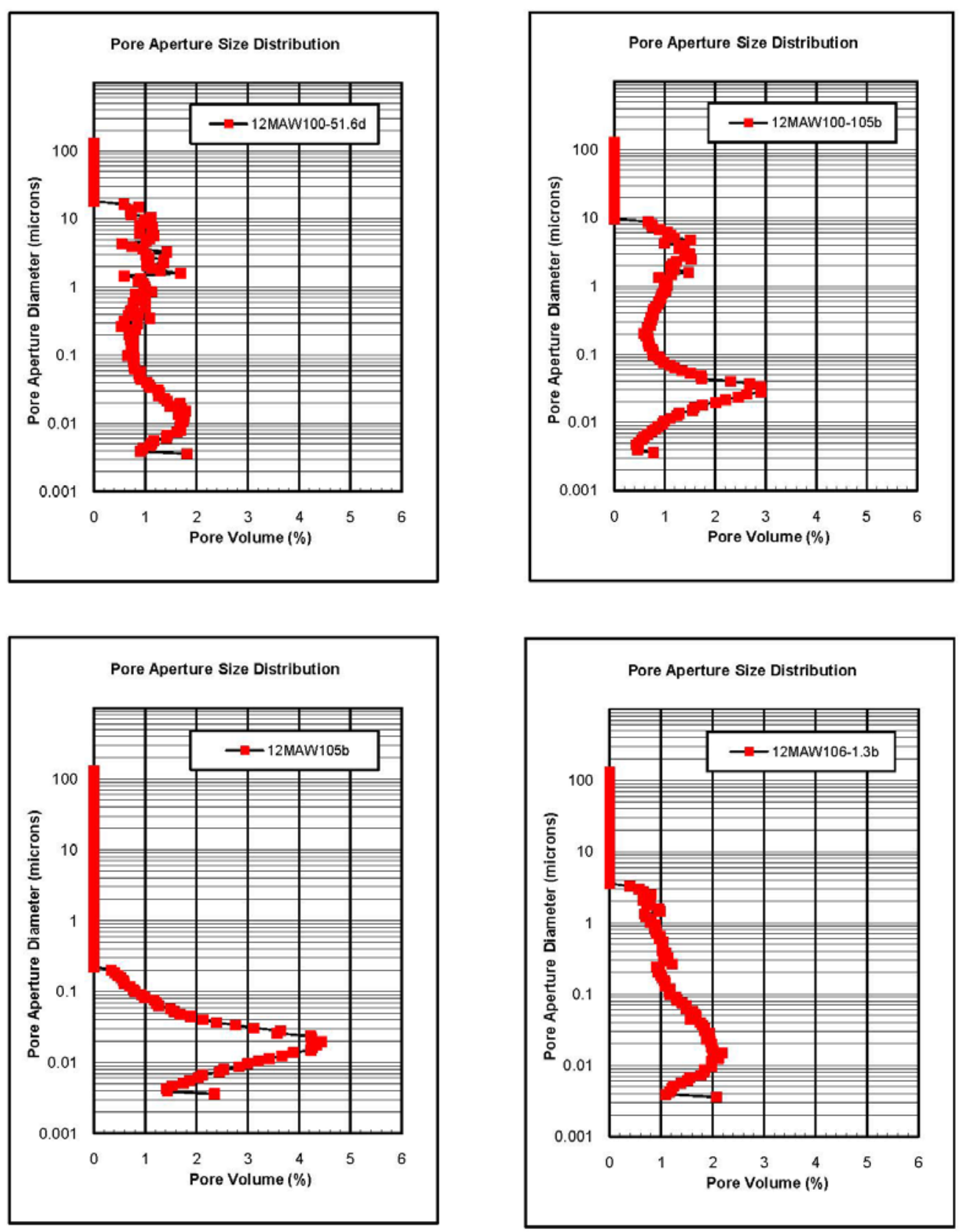
FIGURE 3b

Lower Cook Inlet
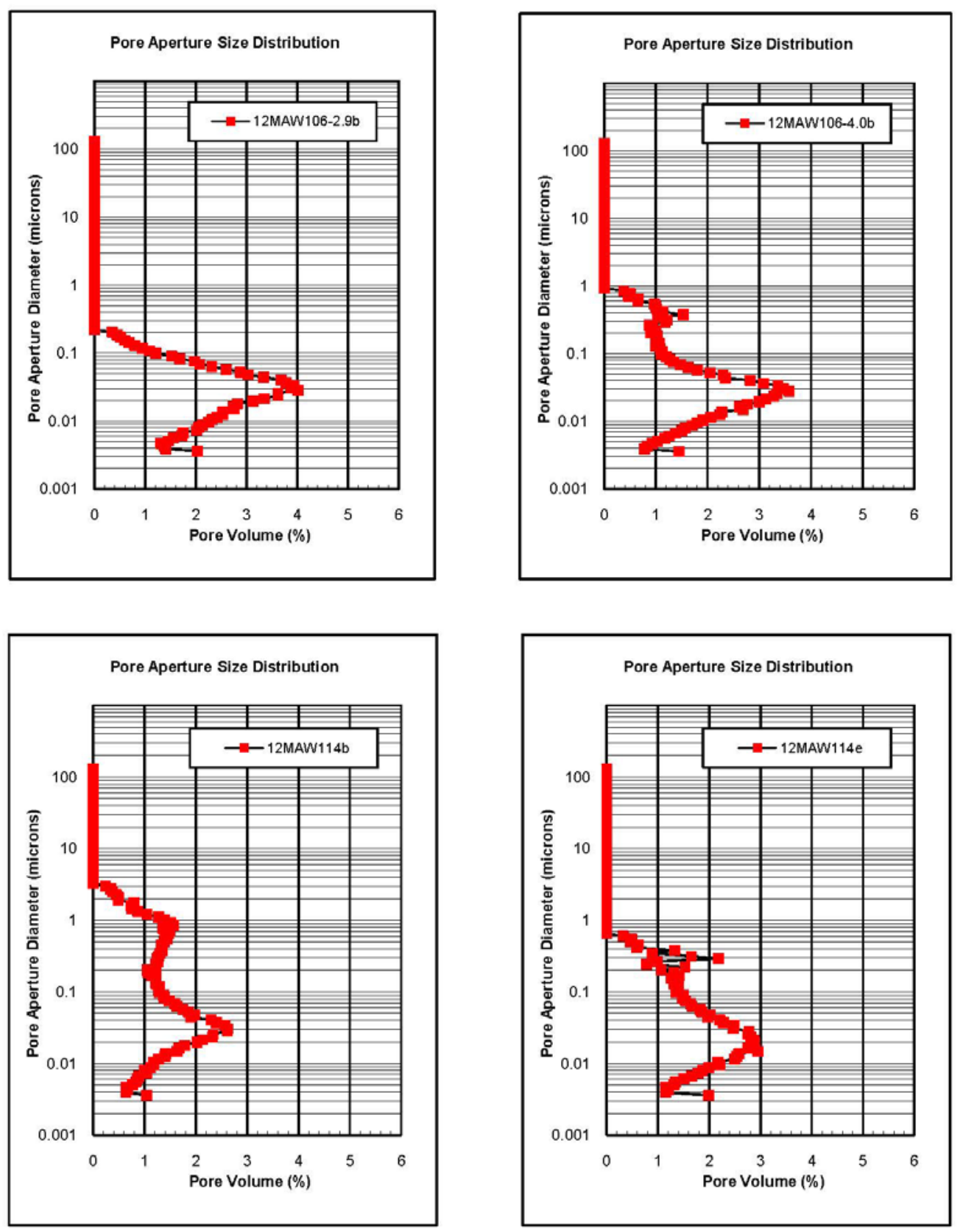
FIGURE 3c

Lower Cook Inlet

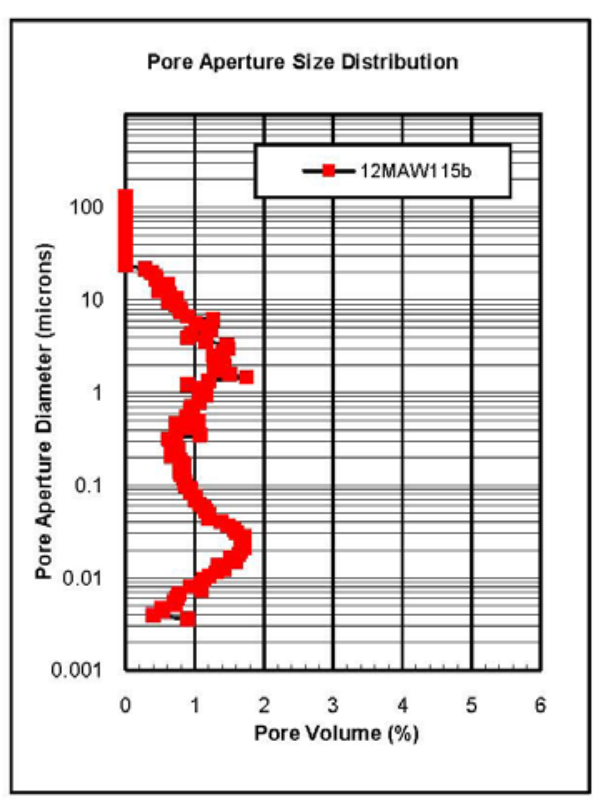

